Available online at https://jurnal.stmikroyal.ac.id/index.php/jurdimas

\title{
PELATIHAN APLIKASI MICROSOFT OFFICE 2010 DAN INTERNET UNTUK PARA SISWA DAN TUTOR PADA LEMBAGA KURSUS PENDIDIKAN (LKP) MANDIRI COMPUTER KABUPATEN ASAHAN SUMATERA UTARA
}

\author{
Yessica Siagian $^{1 *}$, Jeperson Hutahaean ${ }^{1}$, Zulfi Azhar $^{1}$ \\ ${ }^{1}$ Sistem Informasi, STMIK Royal Kisaran \\ email: *yessicacyg.123@gmail.com
}

\begin{abstract}
STMIK Royal Kisaran Community Service Team (PKM) provided training to students of Asahan Regency Mandiri Computer Education Course (LKP), because they saw that there were still many school children and residents around the village who were still very limited in knowledge of computer technology and its applications around the village. there is no nearest computer course. The training material taught at the Mandiri Computer Institute of Training and Education (LKP) is office administration using Microsoft Office 2010 application programs, especially Word, Excel, Power Point and the Internet. Implementation is done by direct practice accompanied by presentations and discussions and using computers to provide direct understanding to students LKP.
\end{abstract}

Keywords: Computer, Institutions Educational Courses,Microsoft Office 2010, Training, Students

Abstrak: Tim Pengabdian kepada masyarakat (PKM) STMIK Royal Kisaran memberikan pelatihan kepada siswa Lembaga Kursus Pendidikan (LKP) Mandiri Computer Kabupaten Asahan, karena memandang masih banyaknya anak sekolah dan penduduk disekitar desa tersebut yang masih sangat minim pengetahuan tentang teknologi komputer beserta aplikasinya dimana disekitar desa tersebut belum ada tempat kursus komputer yang terdekat. Materi pelatihan yang diajarkan di Lembaga Kursus dan Pelatihan (LKP) Mandiri Computer yaitu administrasi perkantoran dengan menggunakan program aplikasi Microsoft Office 2010 khususnya Word, Excel, Power Point dan Internet. Pelaksanaan dilakukan dengan cara praktek langsung disertai dengan presentasi dan diskusi dan menggunakan komputer untuk memberikan pemahaman langsung kepada siswa LKP.

Kata kunci: Komputer, Lembaga Kursus Pendidikan, Microsoft Office 2010, Pelatihan,Siswa

\section{PENDAHULUAN}

Lembaga Kursus Pendidikan

(LKP) Mandiri Computer berada berada

di Jl. Besar Sei Silau Timur Dusun III

Desa Sei Silau Timur Kecamatan Buntu
Pane, Kabupaten Asahan Provinsi Sumatera Utara. Lembaga Kursus dan Pelatihan (LKP) Mandiri Computer mulai berdiri pada bulan April tahun 2011. Adapun hal yang melatar belakangi berdirinya Lembaga Kursus dan 
Available online at https://jurnal.stmikroyal.ac.id/index.php/jurdimas

Pelatihan (LKP) Mandiri Computer ini adalah karena memandang masih banyaknya anak sekolah dan penduduk disekitar desa tersebut yang masih sangat minim pengetahuan tentang teknologi komputer beserta aplikasinya juga disekitar desa tersebut belum ada tempat kursus komputer.

Lembaga Kursus dan Pelatihan (LKP) Mandiri Computer memiliki sarana dan prasarana yang cukup memadai mulai dari buku panduan untuk belajar, kursi, meja, lemari arsip, kipas angin, laptop, printer dan komputer beserta perangkatnya. Ruangan belajar yang bersih dan nyaman. Lembaga Kursus dan Pelatihan (LKP) Mandiri Computer mengalami kemajuan sampai dengan sekarang, baik dari segi fasilitas maupun siswa. Kelebihan dari lembaga ini yaitu memiliki instruktur (tutor) yang ramah dan memiliki wawasan dan pengetahuan yang sesuai dengan bidang ilmunya.

Materi pelatihan yang diajarkan di Lembaga Kursus dan Pelatihan (LKP) Mandiri Computer yaitu administrasi perkantoran dengan menggunakan program aplikasi Microsoft Office 2010 khususnya Word, Excel, Power Point dan Internet. Sebelum memasuki materi pembelajaran tersebut siswa akan diajarkan terlebih dahulu materi pembelajaran dasar-dasar menggunakan komputer untuk mengenal dan menyesuaikan diri dengan sistem operasi yang digunakannya..

\section{METODE}

Tahapan atau langkah-langkah yang ditempuh dalam kegiatan abdimas ini agar terlaksana dengan baik dan lancar mencakup beberapa tahap berikut ini.
1.Persiapan

Koordinasi Internal, dilakukan oleh tim untuk merencanakan pelaksanaan secara konseptual, operasional, serta jobdescription masing-masing anggota

a. Penentuan dan rekruitment peserta pelatihan

b. Pembuatan instrumen abdimas, seperti lembar presensi, angket dan lembar kerja

c. Pembuatan modul pelatihan untuk menambah daya serap peserta. Modul yang diberikan ada 2 jenis modul yaitu materi microsoft office 2010 dan modul internet. Modul tersebut digandakan sebanyak 30 buah baik materi office 2010 maupun materi internet.

d. Persiapan konsumsi, publikasi, lokasi, dokumentasi dan sebagainya.

\section{Pelaksanaan Pelatihan}

a. Memastikan tempat dan fasilitas pendukung seperti infocus, projector dan lain-lain sudah standby pada saat kegiatan akan dilangsungkan

b. Penyajian Materi

Materi yang disajikan terkait dengan Microsoft Office 2010 dan Internet menggunakan modul, slide presentasi, dan alat peraga lainnya. Penyajian materi diploting dalam 2 hari tatap muka. Penyaji materi adalah tim abdimas STMIK Royal yang disesuaikan dengan bidang keahlian masing-masing.

c. Praktik dan Penugasan

Sebelum kegiatan dilakukan peserta harus memiliki komputer atau laptop sebagai alat praktek. Paktek dilakukan secara langsung pada komputer atau laptop dengan panduan modul yang telah diberikan. Kemudian dilanjutkan dengan penugasan untuk menggali 
Available online at https://jurnal.stmikroyal.ac.id/index.php/jurdimas

penyerapan dan pemahaman materi serta melihat kreativitas peserta dalam berkarya. Tim mendampingi, memandu dan mengarahkan serta memberikan solusi apabila timbul permasalahan selama penugasan praktik.

d. Diskusi pemecahan masalah

Diskusi dilaksanakan pada saat pelaksanaan pelatihan dilaksanakan. Diskusi ini ditujukan untuk memberi pendampingan saat pelatihan dan menjawab permasalahan yang ada disetiap materi yang disampaikan. Sedang pemantauan dimaksudkan untuk mengetahui tingkat kemampuan peserta, sehingga materi yang disampaikan menyesuaikan tingkat penyerapan peserta

e. Refleksi dan Penutupan Program Abdimas

Di akhir kegiatan peserta dan Tim melakukan refleksi hasil pelatihan dan para peserta juga memberikan evaluasi akan pelatihan ini. Peserta dapat melihat secara langsung hasil penataan ruang perpustakaan, mengalami proses, serta membandingkan hasil sebelum dan sesudah kegiatan. Setelah semua kegiatan yang telah direncanakan terlaksana, ketua tim Abdimas menutup program dan memberikan pesan kepada segenap peserta pelatihan untuk menerapkan apa yang telah didapatkan. Diharapkan pada Abdimas yang akan akan datang program ini dapat dilanjutkan lagi dan dapat lebih menjangkau jumlah tempat kursus yang ada pada desa lainnya, sehingga kebermanfaatan program ini dapat dirasakan oleh masyarakat yang lebih banyak.

\section{Evaluasi Kegiatan}

Evaluasi kegiatan Abdimas ini dilakukan dengan beberapa cara. Evaluasi hasil dilihat dari tugas praktik para peserta yang ada. Hasil praktiknya dinilai dan hal itu menggambarkan keberhasilan materi yang telah disajikan. Selain itu, secara proses juga dicermati kinerja dan kesertaan para peserta.

4.Pelaporan hasil pelatihan.

Pelaporan hasil dilaksanakan setelah semua kegiatan selesai. Kemudian dianalisa pencapaian terhadap tujuan, faktor pendukung dan faktor penghambat dalam pelaksanaan abdimas ini.

Dalam kegiatan ini pimpinan Lembaga Kursus Pendidikan Mandiri Komputer menyediakan tempat selama kegiatan dilangsungkan dan fasilitasfasilitas penunjang yang mereka punya untuk mendukung kegiatan ini berjalan dengan baik dan lancar.

\section{PEMBAHASAN}

\section{Peserta Kegiatan}

Kegiatan pengabdian kepada masyarakat yang telah dilaksanakan di Lembaga Kursus Pendidikan Mandiri Komputer Sei Silau Timur Kecamatan Buntu Pane Kabupaten Asahan Sumatera Utara pada tanggal 3 - 4 Oktober 2018 dengan tema "Pelatihan Microsoft Office 2010 dan Internet untuk Para Siswa dan Tutor Pada Lembaga Kursus Pendidikan (LKP) Mandiri Computer Kabupaten Asahan Sumatera Utara" dihadiri oleh 26 orang peserta. Para peserta pelatihan 24 orang merupakan anak didik dari Lembaga Kursus Pendidikan (LKP) Mandiri Computer, sedangkan 2 orang merupakan instruktur atau tutor.

\section{Materi Kegiatan}

Berkaitan dengan tema kegiatan, materi- 
Available online at https://jurnal.stmikroyal.ac.id/index.php/jurdimas

materi yang diajarkan dan dipraktekkan adalah sebagai berikut materi kegiatan Microsoft Office 2010 yang terdiri dari : a. Microsoft Word 2010

- Membuat Dan Menyimpan Document Word

- Clipboard (Copy Cut Dan Paste)

- Menduplikat, dan memindahkan kata (Copy, Cut dan Paste)

- Font (Mengatur Huruf, Tabel Dan Pewarnaan)

- Ilustration (Menyisipkan Gambar)

- Header Footer Page Number

- Word Art dan Drop Cap

- Page Setup

- Mail Merge

- Pengaturan

- Memberi Password Dokument

\section{b. Microsoft Excel 2010}

Microsoft Excel adalah program aplikasi spreadsheet yang dikembangkan oleh Microsoft untuk komputer dengan sistem operasi Microsoft Windows dan Mac OS X. Versi pertama Excel untuk Mac dijual di pasar pada tahun 1985, sedangkan versi Windows pada tahun 1987. Versi terakhir saat ini adalah Microsoft Excel 2011 untuk Mac OS X dan Microsoft Excel 2013 untuk Microsoft Windows. Dalam pelatihan ini, versi yang dipakai adalah versi 2010 untuk Microsoft Windows.

\section{c.Microsoft Power Point 2010}

Power point merupakan paket program yang digunakan untuk membantu pembuatan bahan bagi keperluan presentasi. Berbagai daya dukung untuk pembuatan presentasi telah disediakan di program power point. Secara garis besar apa yang dikerjakan di power point meliputi membuat Hyperlink. Fasilitas ini sangat penting dan sangat mendukung pembelajaran karena dengan hyperlink, program bisa terhubung ke program lain atau ke jaringan internet. Hyperlink atau hubungan dalam satu program akan memungkinkan programer memberikan umpan balik secara langsung terhadap proses pembelajaran. Hubungan dengan program lain akan memperkaya fasilitas yang mendukung pembelajaran dan hubungan dengan internet akan membuka berbagai kemungkinan pembelajaran yang lebih luas, pribadi dan otentik. Langkah pembuatan hyperlink adalah dengan memilih objek yang akan kita link ke program lain atau internet. Sesudah kita memilih objek kita mengklik menu insert dan kemudian mengklik menu hyperlink maka akan muncul dialog box dan kemudian kita menuliskan alamat yang dituju misalnya sebuah file atau sebuah situs web dan kemudian mengklik OK maka objek itu akan tersambung ke alamat yang ditulis. Cara yang kedua adalah melalui menu slide show dan kemudian menekan action settings, sesudah itu akan muncul dialog box. Dengan mengisikan alamat dan mengklik OK maka objek akan tersambung ke alamat yang diinginkan. Fasilitas-fasilitas diatas adalah fasilitas utama dalam pengembangan materi pembelajaran dengan Microsoft Powerpoint 2000. Fasilitas yang lain adalah fasilitas tambahan untuk membuat tampilan program lebih menarik dan mudah digunakan

\section{Materi Kegiatan Internet}

a. Browsing

Browsing adalah menelusuri dan melihat website-website mana yang menarik atau diperlukan informasinya untuk kita. Penelusuran dalam internet ini membutuhkan software khusus yaitu software web browser. Salah satu 
Available online at https://jurnal.stmikroyal.ac.id/index.php/jurdimas

software web browser yang saat ini mulai populer digunakan adalah Mozilla Firefox. Program ini bersifat freeware atau diperkenankan untuk digunakan secara bebas asalkan tidak untuk keperluan komersial. Dibandingkan dengan program web browser lain, program ini memiliki beberapa keunggulan yaitu akses yang cepat, keamanan yang baik dan mempunyai feature yang dapat memudahkan proses pencarian

b. Searching

Search engine dalam internet dapat berarti dua hal, pertama adalah suatu website yang memang mengkhususkan diri menyediakan fasilitas pencarian di dunia internet, misal www.google.com dan www.yahoo.com. Jenis kedua adalah search engine dari suatu website, yang hanya bertugas mencari informasi di dalam website yang bersangkutan

c. Download file secara free.

d. Pembuatan dan pengoperasian E-mail

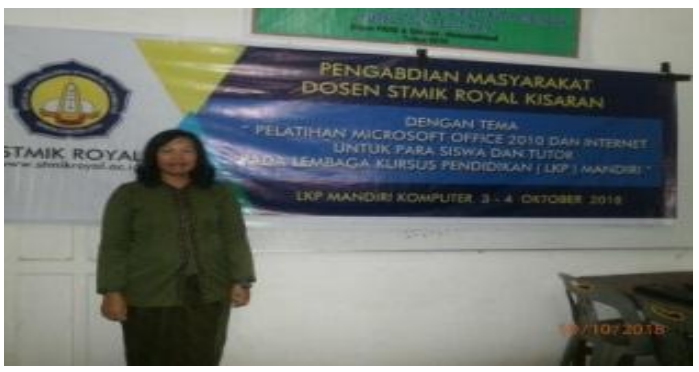

Gambar 1 Pelaksanaan Abdimas di LKP

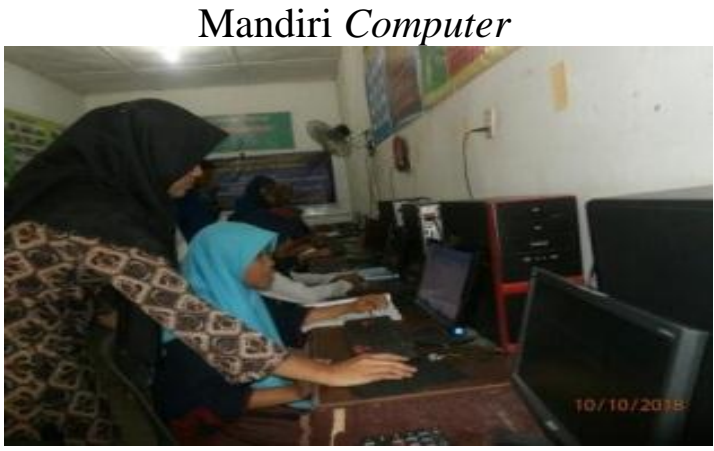

Gambar 2 Tutor Memberikan Pengajaran Kepada Siswa

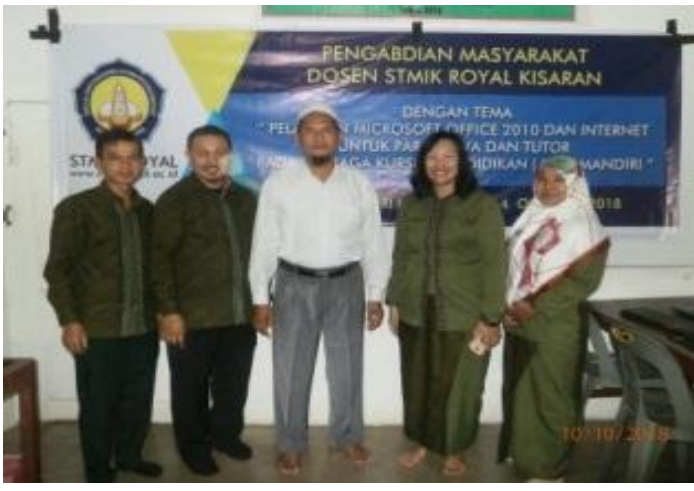

Gambar 3 Pimpinan LKP Mandiri Computer beserta Dosen STMIK Royal Kisaran

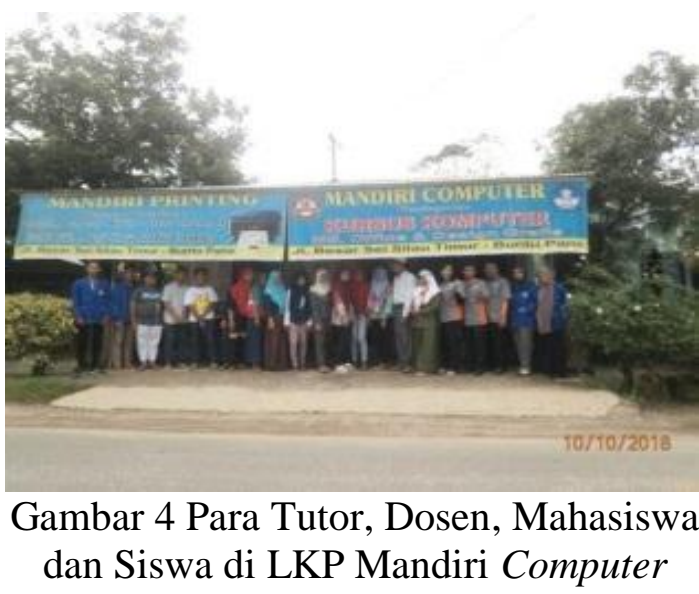

\section{SIMPULAN}

Berdasarkan kegiatan pengabdian kepada masyarakat yang dilakukan pada Lembaga Kursus Pendidikan Komputer Mandiri Computer, Kabupaten Asahan bahwa, kegiatan pengabdian kepada masyarakat yang dilakukan oleh Tim kegiatan (Dosen dan mahasiswa STMIK Royal Kisaran) tepat dan efektif. Materi kegiatan yang diberikan kepada peserta dimanfaatkan dalam menggunakan aplikasi Microsoft Office 2010 beserta internet. Pelaksanaan penyampaian materi terdiri dari beberapa sesi, yaitu: penjelasan, praktek, dan diskusi. Fasilitas yang disediakan oleh pimpinan Lembaga Kursus Pendidikan Mandiri 
Available online at https://jurnal.stmikroyal.ac.id/index.php/jurdimas

Computer sangat lengkap sehingga situasi dan keadaan ruangan sangat nyaman dan aman.

Kegiatan pengabdian kepada masyarakat ini tentunya, tak terlepas dari bantuan berbagai pihak, untuk itu ucapan terima kasih kami sampaikan kepada:

1. Bapak Anda Putra Lubis, SE., MMA, Ketua Yayasan Royal Teladan Asahan, sebagai penyandang dana,

2. Bapak Pimpinan LKP Mandiri Computer beserta seluruh pegawai dan siswanya.

3. Tim pengabdian kepada masyarakat yang telah bekerjasama dengan baik, sehingga kegiatan dapat berjalan lancar dan sukses.

\section{DAFTAR PUSTAKA}

Anonim.2012.http://id.wikipedia.org/wik i/Microsoft_Excel. Diakses tanggal: 29 Juni 2018

Anonim.2012.http://office.microsoft.co $\mathrm{m}$ /en-us/excel/. Diakses tanggal: 29 Juni 2018.

Aziz Lubis, Farhan. 2014.http:// pangeranarti.blogspot.com/2014/1 1/pengertian-microsoft-excellengkap.html. Diakses tanggal: 29 Juni 2018 